compounds, iron and manganese, derived from the land, exert a strongly favourable influence on phyto. plankton production.

The importance of the pack-ice in maintaining the flora within the Antarctic zone is much emphasized. It is even more marked than earlier observations suggested. By means of the pack-ice neritic species are maintained very far from land and flourish for short periods when the ice disperses.

It is here confirmed, as is already noted by former observers (Marshall, Gross and others), that Calanoids are capable of triturating and swallowing the larger spiny diatoms as well as ingesting the smaller species entire. The author's examination of stomach contents showed that in addition to Euphausia superba, other Euphausiids, some of the most important Calanoids and some of the more abundant Pteropods, all feed extensively on diatoms.

\section{INTERNATIONAL LAW AND MORALS}

$\mathrm{P}_{\mathrm{r}}^{\mathrm{H}}$ ROF. MORRIS GINSBERG wisely chose for his presidential address to the Aristotelian Society* a theme relevant both to his own distinguished work as a sociologist and to the world erisis which perforce dominates public attention at the present time. $\mathrm{He}$ sets himself to show how the trend towards an individualist doctrine in ethies is discernible also in recent developments of international law, attended there by "a certain lag in applying the criticisms which in the course of the nineteenth century were directed against the principles of individualism" (for example, the right of property and freedom of contract) in the internal economy of States, to the problem of the relations between States, a lag that is in no small measure responsible for our present international troubles and calls urgently for rectification. The only remedy, he contends (and the contention is supported by much judicious illustration), lies in the establishment of an effective supra-national authority. It makes little difference to this conclusion whether a utilitarian criterion or a doctrine of natural rights be adopted as the basis of the theory of international law; for the advocates of both these positions have carried the individualist interpretation to an extreme that precludes any satisfactory solution of international problems. Prof. Ginsberg's discussion of the concepts of equality, freedom and self-determination and of the difficulties provoked by each when held to be natural rights is perhaps the most masterly section of his address.

Three points in his review call for special notice. Not only is he convinced that the problem of international relations is a moral one ; but it is so regarded by public opinion, both at home and, as has erroneously been questioned, in enemy countries. Nazi propaganda has won its way in Germany by an appeal to justice and denunciation of the alleged injustice of which Germany has been the victim. The theorists of the movement "even go to the length of claiming that they have bridged the gulf between law and morals and that their law alone is richtiges Recht". It is vitally important for us all to realize that the conflict in which we are engaged is being fought out

*"The Individualist Basis of International Law and Morals", by Morris Ginsberg, being the Presidential Address to the Aristotelian Society, 1942-3. on ethical terrain by both sides. It is a conflict of one set of moral principles against another.

Secondly, on both sides, the ethical concept of justice is in the forefront. Prof. Ginsberg follows Sidgwick in holding that the principle of seeking happiness needs supplementing by that of just distribution. So, again, there can be no peace among the nations without justice, and justice implies positive co-operation for common ends. Lastly, he has some interesting remarks towards the close on the error, into which many thinkers on politics have fallen, of presenting the issue now before the world as whether the individual exists for the State or the State for the individual. To posit the antithesis thus is to over-simplify the real problem. "There is clearly a need," he says, "for a great variety of corporate bodies to mediate between the mass of individuals and the community of mankind." This need is increasingly urgent in the larger among modern States, and is winning recognition in federal communities like the British Commonwealth, the American Union and the U.S.S.R. A great deal of the work of self-government is carried on, not within the bounds of constitutional machinery (where the individual citizen scarcely counts, even when he is voting), but through participation in non-official groups, churches, universities and learned societies, professional organizations and trade unions.

We are duly grateful to Prof. Ginsberg for directing attention to the part such groups may play in the solution of international problems.

W. G. DE BURGH.

\section{CIVILIAN CONTRIBUTION TO EDUCATION IN H.M. FORCES}

$\mathrm{T}$

HE report of the Central Advisory Council for Adult Education in H.M. Forces for the period April-September 1942 reflects great credit on all the civilian authorities who constitute the Central Advisory Council. The launching of the educational scheme in the Forces could scarcely have been possible without the active participation of the Central Advisory Council, while any success it may have achieved is due in large measure to the substantial assistance provided by the regional committees of the Central Advisory Council in the various administrative areas. It is early yet to assess the real worth of this tremendous educational experiment, but already there is sufficient evidence to show that, by means of talks and discussions on various aspects of citizenship, those who have been responsible for the development of education in the Fighting Services have done much to develop a sense of civic awareness and responsibility among the people who are the potential citizens of Great Britain. Despite the difficulties of travelling in the black-out, the geographical isolation of Army and Air Force units, the cancellation of lectures at short notice owing to military exigencies and other factors which give rise to a considerable amount of exasperation and frustration, civilian lecturers have steadily continued to offer their services under the Scheme for Education in H.M. Forces. The statements in this report bear testimony to their achievements.

An analysis of the statistics brings out some interesting observations. During the period under review (April 1942-September 1942) the Central Advisory Council arranged some 44,695 single 
lectures, 2,513 short courses (average, 5 meetings) and 1,030 continuouśs classes of longer duration (average, 13 meetings). A comparison of these figures with those of the preceding six months $(29,970$ single lectures, 1,785 short courses and 1,097 classes), indicates the progress of the scheme. It should be mentioned that these figures do not include lectures and classes arranged by local education authorities direct with the Services.

As one might expect, the greatest number of these lectures, etc., were given to Army units, but it is encouraging to note the increase in number of lectures to the Royal Air Force and the Navy. It is impossible to obtain accurate figures to show how much advantage is taken by the Women's Services of the regional committee facilities because there is no way of ascertaining the number of women attending in mixed audiences. But there is little doubt that the educational scheme has 'caught on' with the women auxiliaries, and this is clearly indicated by the figures set out in the report for all-women facilities.

A survey of the subjects which were discussed at these lectures and classes shows, as one might expect, the single lectures on current events are mostly in demand by the troops $(29,419$ out of a total 39,031$)$. Science lectures are divided into two categories, vocational and non-vocational, and provided 264 and 2,287 lectures respectively; psychology is listed as a separate item and accounted for 493 lectures. There were 979 single lectures on arts subjects.

As in single lectures, current affairs were much the most popular choices in the short courses $(1,664$ out of 2,420 ), but the outstanding feature here is the interest shown in short courses on music (135 out of a total of 2,420). Among the classes, languages were mostly demanded (334 out of 970) while handicrafts $(272)$ were also in favour. Vocational science classes were quite popular (131), but there was little demand for non-vocational science (12 classes only).

Some doubts are expressed as to whether the regional committees will be able to meet the increasing demands being made upon them. But for the time being, at least, this problem seems possible of solution by the more effective use of already existing panels of lecturers. The appointment of more full-time lecturers to the regional committees would do much to ease their difficulties.

\section{CHEMICAL ATTACK UPON PESTS}

$I^{N}$ time of war, man becomes pest- and diseaseconscious. Under its abnormal and stringent conditions, leading to overcrowding and lack of vigilance, he, his domestic animals, his food plants, and to some extent his very clothing may become more susceptible to attack by pests and disease. War and pestilence interlock, but with increasing scientific knowledge we have ceased to regard the latter as an act of God before which we are powerless. Since the War of 1914-18, there has probably been a greater advance in the development of pest and disease control than in all past history. Much of this progress undoubtedly has been due to extensive and intensive co-operation of biologists and chemists. The early triumphs of chemotherapy gave an impetus to research outside the purely medical field, which was based upon the belief that in chemistry there existed a potential arsenal that might well be turned to account for purposes of pest control.

In a paper read before the Royal Society of Arts on March 31, Dr. R. E. Slade developed in the simplest language the story of the chemical methods now used for this purpose. Although almost any modern allotment holder knows the way, and possesses the means, of controlling many of the pests preying on his plants, a lecture of this type serves a most useful purpose in giving to the general public a co-ordinatied account of a very large part of this field of research and in showing by implication how extensively and intimately it affects man's wellbeing. But surely Dr. Slade spreads his net too widely if "inconvenience to man" is to be specified as the main feature of a pest. Many birds may on occasion be an inconvenience in our gardens, but the species that rank as pests are few, and they detrimentally affect man's well-being. A dire word should surely be retained for grave ends.

It has frequently been stressed that most of the important insecticides and fungicides have keen known for many years and that chemical research has added few to their number. Dr. Slade only in part answers this challenge, and confesses that chemists are finding the replacement of certain insecticides a formidable task. Many discoveries in all branches of science and industry have been due to chance, but their systematic improvement and development have been the result of strenuous and systematic research. The discovery of derris root in 1848 by Oxley was apparently a chance one, but its introduction to the Western world by Durham was the result of scientific research, its improvement resulted from years of selection research by Georgi and his co-workers in the Department of Agriculture in Malaya, and the structure of its active principles from the labours of a number of scientifie men. Here one notes a feature which adds to the chemist's difficulties-the structural asymmetry of the insecticidal principles derived from plants, and the dependence of their very potent toxic action upon minute particulars in specific structures. The need at present, at least upon the research side, is a more intimate physiological knowledge of how these potent principles act. The co-ordination of effort between chemist, physicist and biologist, which Dr. Slade rightly stressed, needs carrying, and will be carried, a further stage.

Such a consideration is true in the fungicide field as well, but with a slightly different orientation. This field of work is closer in character to that of chemotherapy, and in the case of seed dressings and in the use of certain organic colouring matters as fungicides has at least benefited by the association.

Dr. Slade dealt only very shortly with the technical procedures used in the laboratory or the field for evaluating results. But to both of these much research has been devoted, and also to the statistical methods of analysing the data accumulated and stating their significance. It thus happens that whereas twenty-five years ago only a general personal impression of a roughly qualitative kind could be given of the relative merits of various chemical control measures, to-day, a degree of certainty which is at least as great as that obtained in the majority of biological experiments can be realized.

Dr. Slade's lecture was almost strictly impersonal in its outlook and dealt severely with facts; history, theory and generalization being eschewed: But. such pioneers as H. E. Durham and J. D. 